\title{
A taxonomic and biogeographic review of the fossil tapirs from Bolivia
}

Brenda S. Ferrero, Esteban Soibelzon, Elizete C. Holanda, Germán M. Gasparini, Alfredo E. Zurita, and Ángel R. Miño-Boilini

Acta Palaeontologica Polonica 59 (3), 2014: 505-516 doi: http://dx.doi.org/10.4202/app.2012.0041

Fossil remains of South American tapirs are often fragmentary and scarce compared with those of other mammals that entered South America during the "Great American Biotic Interchange". Here, we review and add to the Pleistocene tapir remains from the Tarija Valley (Bolivia), and provide a taxonomic re-evaluation of Tapirus tarijensis. T. tarijensis was a large-sized animal, approximating the size of the living Malaysian T. indicus and the extinct North American T. haysii . The geographical distribution of Pleistocene records of Tapirus in South America indicates that $T$. tarijensis was the only known species inhabiting the Tarija Valley during this time.

Key words: Mammalia, Perissodactyla, tapirs, Tapirus tarijensis, Quaternary, Tarija Valley, South America.

Brenda S. Ferrero [brendaferrero@yahoo.com.ar], Laboratorio de Paleontología de Vertebrados, Centro de Investigaciones Científicas y Transferencia de Tecnología a la Producción de Diamante (CICYTTP-CONICET), Materi y España s/n, 3105, Diamante, Entre Ríos, Argentina; Esteban Soibelzon [esoibelzon@fcnym.unlp.edu.ar], and Germán M. Gasparini [germanmgasparini@gmail.com], CONICET, División Paleontología Vertebrados, Museo de La Plata, Paseo del Bosque, s/n, 1900 La Plata, Argentina; Elizete C. Holanda [elizete.holanda@gmail.com], Departamento de Geologia, Instituto de Geociências, Universidade Federal de Roraima, Av. Cap. Ene Garcez, 2413, Aeroporto, Boa Vista, Roraima, Brazil; Alfredo E. Zurita [azurita@cecoal.com.ar] and Ángel R. Miño-Boilini [angelmioboilini@yahoo.com.ar] Centro de Ecología Aplicada del Litoral (CECOALCONICET) y Universidad Nacional del Nordeste. Ruta 5, km. 2,5 CC 128 (3400), Corrientes, Argentina. 
distribution, and reproduction in any medium, provided the original author and source are credited.

Pores Full text $(620.9 \mathrm{kB})$ ।

ErFi: Supplementary file $(69.8 \mathrm{kB})$ 